\title{
Yield Gap Analysis for Groundnut through Cluster Front Line Demonstration in South Eastern Ghat Zone of Odisha
}

\author{
Samir Ranjan Dash ${ }^{1}$, Nigamananda Behera ${ }^{1}$, Himangshu Das ${ }^{2 *}$, Anuj Kumar Rai ${ }^{1}$, \\ B.K. Rautaray ${ }^{3}$ and N. Bar ${ }^{4}$
}

${ }^{1}$ Krishi Vigyan Kendra, Malakngiri (OUAT), Odisha, India

${ }^{2}$ Regional Research \& Technology Transfer Sub-Station, Kalimela (OUAT), Malkangiri, Odisha, India

${ }^{3}$ Krishi Vigyan Kendra, Jagatsinghpur (OUAT), Odisha, India

${ }^{4}$ Krishi Vigyan Kendra, Nabarangapur (OUAT), Odisha, India

'Corresponding author: hdubkv@gmail.com (ORCID ID: 0000-0003-1568-9544)

Paper No. 899

Received: 10-02-2021

Revised: 22-05-2021

Accepted: 06-06-2021

\begin{abstract}
A study was carried out by the Krishi Vigyan Kendra, Malkangiri during 2018-19 to find out the yield gap between farmer's practices and demonstration practices through cluster front line demonstration in South Eastern Ghat Zone of Odisha. The results showed a 32.9\% increase in the average yield of groundnut with demonstration practices as compared to farmer's practices. Higher economic return was also obtained with demonstration practices. The average technology gap, extension gap, and technology index were $3.2 \mathrm{q} / \mathrm{ha}, 5.4 \mathrm{q} / \mathrm{ha}$, and $12.8 \%$, respectively. The yield potential of groundnut could be enhanced to a great extent through cluster front line demonstration with improved production technologies. Hence, it is necessary to educate the farming community for more adoption of improved cultivation techniques of groundnut to increase productivity and economic return.

\section{HIGHLIGHTS}

0 Main reason for low groundnut yield in the case of existing farmer's practices in the South Eastern Ghat Zone of Odisha was the non-adoption of an improved package of practices.

( $)$ An extension gap of $5.4 \mathrm{q} /$ ha was observed from this study. Hence, it is necessary to educate the farmers for more adoption of improved cultivation techniques of groundnut.
\end{abstract}

Keywords: Demonstration, groundnut, production technologies, the yield gap

Groundnut (Arachis hypogaea $\mathrm{L}$ ) is one of the most important oilseed crops grown in India. Groundnuts are a rich source of protein, fat, and various healthy nutrients. Groundnut kernel contains $44-56 \%$ oil and $22-30 \%$ protein on a dry mass basis and rich source of minerals (phosphorus, calcium, magnesium, and potassium) and vitamins (E, $\mathrm{K}$, and $\mathrm{B}$ group) (Ingale and Shrivastava 2011). In India, groundnut occupying 5.02 million ha area with production of 8.11 million tonnes (Anonymous 2019). Groundnut is an important oilseed crop of Odisha and covered an area of 221.29 thousand ha with a production of 387.19 thousand tones (Anonymous 2015-16). South Eastern Ghat Zone of Odisha mainly comprising of Malkangiri district, and it has been considered as a productively potential region of groundnut due to assured irrigation facilities and favorable soil and climate conditions. In Malkangiri district, groundnut is cultivated in an area of 10.33 thousand ha with a productivity of $1844 \mathrm{~kg} / \mathrm{ha}$ (Anonymous 2015-16). However, there is a wide gap between the potential and the actual production realized by the farmers due to the partial adoption of recommended package of practices by the growers. Several constraints contribute to yield fluctuation

\footnotetext{
How to cite this article: Dash, S.R., Behera, N., Das, H., Rai, A.K., Rautaray, B.K. and Bar, N. 2021. Yield Gap Analysis for Groundnut through Cluster Front Line Demonstration in South-Eastern Ghat Zone of Odisha. IJAEB, 14(2): 199-202.
}

Source of Support: None; Conflict of Interest: None 
on groundnut production, including unreliable rainfall, lack of high yielding disease tolerant varieties, the appearance of pests and diseases, low producer prices, poor agronomic practices, and lack of institutional support (Bucheyeki et al. 2008; Okoko et al. 1999). Cluster front line demonstration (CFLD) program of groundnut has been implemented through Krishi Vigyan Kendras (KVKs) to boost the production and productivity of this crop. The actual groundnut yield at the farm level depends on the management aspect that is associated with socioeconomic in addition to biophysical factors (Bindraban et al. 2020). The main objective of front-line demonstrations is to demonstrate newly released crop production technologies and their management practices in the farmers' field under different farming situations and at different agro-climatic regions. Keeping the above point in view, the CFLD on groundnut using improved production technologies was conducted by Krishi Vigyan Kendra, Malkangiri, under the supervision of agricultural scientists and the seeds of high yielding variety ICGV- 91114 (Devi), and other critical inputs were provided to the farmers to find out yield gaps between farmer's practices and demonstration practices.

\section{MATERIALS AND METHODS}

The study was carried out by Krishi Vigyan Kendra (KVK), Malkangiri, during the winter season of 2018-19 in the Kalimela block of Malkangiri district of Odisha. This block was selected purposefully as groundnut is the major oilseed crop. The demonstrations were conducted in two different adopted villages, i.e., MV- 67 and MV- 25, in a cluster approach. Sixty numbers of beneficiaries were selected by conducting group meetings, and all the participating farmers were trained on various aspects of groundnut production technologies and recommended agronomic practices. The total area covered under demonstration was $20 \mathrm{ha}$, and the plot size of the individual farmer was 0.2 to 0.4 ha. The soil of the demonstration site was slightly acidic in reaction ( $\mathrm{pH}-5.0$ to 5.3) with sandy loam in texture. The available nitrogen, phosphorus, and potassium were varied between 180.8-210.3, 14.019.8, and 131.1-140.5 Kg/ha, respectively.

The crop was sown under irrigated conditions in the second week of January. The crop was raised with recommended agronomic practices (Table 1) and harvested within the fourth week of March to the first week of April. In the case of local checks, existing practices being used by farmers were followed (Table 1). The observations like plant height, number of pods/plant, 100 seed weight, and seed yield were recorded at harvest from demonstrated as well as from farmer's practiced plot. Gross returns ( $₹ /$ ha) were calculated on the basis of the prevailing market price of the groundnut, i.e., ₹ 4000 per quintal. Net return ( $₹ / h a)$ was calculated by deducting the cost of cultivation from gross return. B: C ratio was calculated by dividing the total cost of cultivation by gross return. Following formulae have been used to estimate the technology gap, extension gap, and technology index as per Samui et al. (2000):

Technology gap $=$ Potential yield - Demonstration yield ------- (I)

Extension gap $=$ Demonstration yield - Farmer's yield ------- (II)

Technology index $=\{($ Potential yield - Demonstration yield)/Potential yield\} x 100 ----- (III)

\section{RESULTS AND DISCUSSION}

The study result revealed that major differences were observed between demonstration packages and farmer's practices were regarding varieties, seed treatment, fertilizer application, method of weed management, and plant protection measures (Table 1 ). This was mainly because farmers are unaware of a suitable package of practices for groundnut. The findings are corroborated with some other findings (Singh and Chaudhari 1995; Katare et al. 2011). Recorded data viz. plant height, a number of pods/plant, 100 kernel weight, as well as pod yield of groundnut in the demonstrated plot was higher than that of farmer's practice (Table 2). The average plant height of groundnut under demonstrated variety Devi was $24.2 \mathrm{~cm}$ as compared to $21.6 \mathrm{~cm}$ in the case of farmer's practice. Demonstrated plots recorded a $29.4 \%$ higher number of pods and $28.2 \%$ more 100 kernel weight as compared to farmers' practice. The results indicated that the average pod yield of groundnut in farmer's practices was $16.4 \mathrm{q} / \mathrm{ha}$, and it was $21.8 \mathrm{q} / \mathrm{ha}$ in the demonstrated plot. The increased in groundnut yield in the demonstrated plot was due to be suitable variety, adequate seed rate, seed treatment, balance dose of 
Table 1: Variation in a package of practices for farmer's practices and demonstrated technology for groundnut

\begin{tabular}{|c|c|c|c|}
\hline S1. No. & Package of practices & Farmer's practice & Demonstrated technology \\
\hline 1 & Variety & Kadri - 6 & ICGV- 91114 (Devi) \\
\hline 2 & Seed rate & $150 \mathrm{~kg} / \mathrm{ha}$ & $125 \mathrm{~kg} / \mathrm{ha}$ \\
\hline 4 & Method of sowing & Seed dropping behind the plough & Line sowing with spacing of $25 \times 10 \mathrm{~cm}$. \\
\hline 5 & Fertilizer application & $\begin{array}{l}\text { Irrational use of nitrogenous } \\
\text { fertilizer without Sulphur } \\
\text { application }\end{array}$ & $\begin{array}{l}\text { Fertilizer dose of } 20,40 \text { and } 40 \mathrm{~kg} \mathrm{~N}, \mathrm{P}_{2} \mathrm{O}_{5} \text { and } \mathrm{K}_{2} \mathrm{O} \text { per ha, } \\
\text { respectively along with Sulphur @ } 20 \mathrm{~kg} / \mathrm{ha} \text {. }\end{array}$ \\
\hline 6 & $\begin{array}{l}\text { Insect-pests and } \\
\text { disease management }\end{array}$ & $\begin{array}{l}\text { Use of Insecticide like Dimethoate, } \\
\text { Imidacloprid, and Chlorpyrifos }\end{array}$ & $\begin{array}{l}\text { Spraying of Thiomethoxam } 25 \% \text { WG @ } 0.2 \mathrm{~g} / \text { litre of } \\
\text { water for management of sucking pests. Spraying of } \\
\text { Profenophos } 50 \% \text { EC @ } 2 \mathrm{ml} / \text { litre of water for pest } \\
\text { management like red hairy caterpillar and tobacco } \\
\text { caterpillar. Drenching with Metalaxyl-M } 8 \%+\text { Mancozeb } \\
64 \% \text { WP } @ 2 \mathrm{~g} / \text { litre of water for management of collar rot. }\end{array}$ \\
\hline
\end{tabular}

Table 2: Growth and yield parameters under farmer's practices and demonstration packages for groundnut cultivation

\begin{tabular}{|c|c|c|c|c|c|}
\hline Particulars & $\begin{array}{l}\text { Plant height at } 90 \\
\text { DAS }(\mathrm{cm})\end{array}$ & $\begin{array}{l}\text { No. of pods/ } \\
\text { plant }\end{array}$ & $\begin{array}{l}100 \text { kernel } \\
\text { weight }(\mathrm{g})\end{array}$ & $\begin{array}{l}\text { Pod yield } \\
\text { (q/ha ) }\end{array}$ & $\begin{array}{l}\text { Harvest } \\
\text { Index }\end{array}$ \\
\hline Farmer's practice & 21.6 & 17 & 42.6 & 16.4 & 52.3 \\
\hline Demonstration practice & 24.2 & 22 & 54.6 & 21.8 & 56.4 \\
\hline
\end{tabular}

Table 3: Yield comparison of groundnut under farmer's practices and demonstration practices

\begin{tabular}{llllll}
\hline Particulars & $\begin{array}{l}\text { Mean Yield } \\
\text { (q/ha ) }\end{array}$ & $\begin{array}{l}\text { Standard } \\
\text { Deviation }\end{array}$ & CV\% & $\begin{array}{l}\text { \% increase over } \\
\text { farmer's practices }\end{array}$ & 'Z' Value \\
\hline Farmer's practice & 16.4 & 1.17 & 7.18 & \multirow{2}{*}{32.92} & $25.949^{*}$ \\
\hline Demonstration practice & 21.8 & 1.09 & 5.03 & & \\
\hline
\end{tabular}

The test statistic Z equals - 25.949; ${ }^{*}$ Indicates significance value at $p=0.05$.

fertilizer application, and proper plant protection measures. On the other hand, an inappropriate package of practices gave lower yields in farmer's practices. Superior impact by intervention practices on groundnut was also observed in others carried out work (Pawar et al. 2018; Solanki and Nagar 2020). The calculated ' $Z$ ' value (25.949) was found to be significant, indicating a significant difference in yield between farmer's practice and recommended practice. It was concluded that yield variation was more in the case of farmer's practices as compared to demonstration practices, as CV was more (7.18\%) in farmer's practices (Table 3).

This study showed a technological gap of $3.2 \mathrm{q} /$ ha (Table 4). Response of variety to a different environment is varied, and the observed technology gap might be due to variation in soil and weather conditions. So, it is necessary to develop a of varietywise location-specific packages of practices to bridge the technology gap. An extension gap of $5.4 \mathrm{q} / \mathrm{h}$ a was observed from this study. This extension gap should be assigned to the adoption of suitable cultivation packages in demonstration practices. Hence, it is necessary to educate the farmers for more adoption of improved cultivation techniques of groundnut. On the other hand, the technology index shows the feasibility of technology in farmer's fields. The lower value of the technology index shows more feasibility. Overall technology index of $12.8 \%$ recorded in this study. This emphasized the role of Krishi Vigyan Kendra or other line departments to train the non-beneficiary farmers through various means for the adoption of improved cultivation practices of groundnut. These analytical findings 
Table 4: Yield gap analysis under cluster front line demonstration of groundnut at farmers' field

\begin{tabular}{lllll}
\hline Particulars & $\begin{array}{l}\text { Average yield } \\
(\mathbf{q} / \mathbf{h a})\end{array}$ & $\begin{array}{l}\text { Technology gap } \\
(\mathbf{q} / \text { ha })\end{array}$ & $\begin{array}{l}\text { Extension gap (q/ } \\
\text { ha) }\end{array}$ & $\begin{array}{l}\text { Technology Index } \\
(\%)\end{array}$ \\
\hline $\begin{array}{l}\text { Farmer's practice } \\
\text { Demonstration practice }\end{array}$ & 16.4 & 3.2 & 5.4 & 12.8 \\
\hline
\end{tabular}

Table 5: Economic comparison between farmer's practices and demonstration packages for groundnut cultivation

\begin{tabular}{lllll}
\hline Particulars & $\begin{array}{l}\text { Cost of cultivation } \\
\text { (₹/ha) }\end{array}$ & $\begin{array}{l}\text { Gross return } \\
\text { (₹/ha) }\end{array}$ & $\begin{array}{l}\text { Net return } \\
\text { (₹/ha) }\end{array}$ & B:C ratio \\
\hline Farmer's practice & 32200 & 65600 & 33400 & 2.04 \\
Demonstration practice & 37400 & 87200 & 49800 & 2.33 \\
\hline
\end{tabular}

were in agreement with the others work carried out by Pawar et al. (2018) and Solanki and Nagar (2020).

The total cost of cultivation for demonstration practice was higher as compared to farmer's practice (Table 5) due to the additional cost involved in an improved package of practices with demonstration plots. Higher gross return ( $₹ 87200 /$ ha), net return (₹ 49800/ha), and B:C ratio (2.33) were obtained where the crop was cultivated under cluster front line demonstration. Higher economic return was obtained with demonstration practices because of increased groundnut yield by $32.9 \%$, whereas an increase in the cost of cultivation was less, i.e., $16.1 \%$ with demonstration practices as compared to farmer's practices.

\section{CONCLUSION}

The study showed the positive response of cluster front line demonstration over the existing practices in respect to yield enhancement and economic return of groundnut in the South Eastern Ghat Zone of Odisha. The principal reason of the lower productivity of groundnut in case of existing farmer's practices in the South Eastern Ghat Zone of Odisha was the non-adoption of an improved package of practices. Differences between demonstration and farmer's practices (extension gap) emphasize the need to educate farmers in respect to different improved production technologies of groundnut by different extension agencies.

\section{REFERENCES}

Anonymous. 2015-16. Odisha agriculture statistics 2015-16, Directorate of Agriculture \& Food Production, Govt. of Odisha.
Anonymous. 2019. Agriculture statistics at a glance 2019. Government of India, Ministry of Agriculture \& Farmers Welfare, Department of Agriculture, Cooperation \& Farmers Welfare, Directorate of Economics and Statistics. New Delhi.

Bindraban, P.S., Stoorvogel, J.J., Jansen, D.M., Vlaming, J. and Groot, J.J.R. 2000. Land quality indicators for sustainable land management: Proposed method for yield gap and soil nutrient balance. Agric. Ecosyst. Env., 81(2): 103-112.

Bucheyeki, T.L., Shenkalwa, E.M., Mapunda, T.X. and Matata, L.W. 2008. On-farm evaluation of promising groundnut varieties for adaptation and adoption in Tanzania. African J. Agric. Res., 3(8): 531-536.

Ingale, S. and Shrivastava, S.K. 2011. Nutritional study of new variety of groundnut (Arachis hypogaea L.) JL-24 seeds. African J. Food Sci., 5(8): 490-498.

Katare, S., Pandey, S.K. and Mustafa, M. 2011. Yield gap analysis of Rapeseed-mustard through front line demonstration. Agric. Update, 6(2): 5-7.

Okoko, E.N.K., Rees, D.J., Kwach, J.K. and Ochieng, P. 1999. Participatory evaluation of groundnut production Southwest Kenya. In: Towards Increased Use of Demand Driven Technology KARI/DFID NARP II PROJECT, Nairobi Kenya, pp. 305-307.

Pawar, Y.D., Malve, S.H., Chaudhary, F.K., Dobariya, U. and Patel, G.J. 2018. Yield gap analysis of groundnut through cluster front line demonstration under north Gujarat condition. Multilogic in Sci., VII(XXV): 177-179.

Samui, S.K., Maitra, S., Roy, D.K., Mandal, A.K. and Saha, D. 2000. Evaluation of front line demonstration on groundnut. J. Indian Soc. Coast. Agric. Res., 18(2): 180-183.

Singh, A.L. and Chaudhari, V. 1995. Source and mode of sulphur application on groundnut productivity. J. Plant Nutr., 18(12): 2739-2759.

Solanki, R.L. and Nagar, K.C. 2020. Yield and gap analysis of groundnut (Arachis hypogaea L.) productivity through frontline demonstration in district Chittorgarh of Rajasthan, India. Int. J.Curr. Microbiol. Appl. Sci., 9(6): 4119-4125. 